\title{
Обзор личного фонда П. Э. Алексеевой*
}

\section{A Review of P. E. Alekseeva's Personal Fond}

\section{Делгир Юрьевна Топалова (D. Tораlova) ${ }^{1}$}

${ }^{1}$ Калмыцкий научный центр РАН (д. 8, ул. им. И. К. Илишкина, 358000 г. Элиста, Российская Федерация) кандидат филологических наук, научный сотрудник ORCID: 0000-0002-1932-6452. E-mail: delya.top@yandex.ru

Kalmyk Scientific Center of the RAS (8, Ilishkin St., Elista, 358000, Russian Federation)

Cand. Sc. (Phil.), Research Associate

ORCID: 0000-0002-1932-6452.E-mail: delya.top@yandex.ru

Аннотация. В статье представлено описание архивных материалов личного фонда П. Э. Алексеевой - основателя научной библиотеки КалмНЦ РАН, главного библиографа, исследователя. На основе хранящихся архивных материалов фонда, в котором насчитывается 426 единиц хранения, согласно основным правилам работы с архивными делами, в фонде было выделены три раздела. Небольшой анализ каждого из них (за исключением третьего, в котором хранятся фотоматериалы) позволил детально проследить творческую биографию фондообразователя. Самая большая, первая группа документов, - «Научные труды и творческие материалы», в которой хранятся черновики опубликованных статей и монографий, была разделена на четыре основные подгруппы (история, фольклор, этнография и религия, а также калмыцкое зарубежье). Вторая группа — «Переписка» содержит письма рабочего характера, а именно переписку Прасковьи Эрдниевны с российскими и зарубежными учеными (А. Борманжинов, Д. Крюгер, Е. Е. Лангерфельд, Ф. Д. Шульман, С. Ю. Неклюдов и др.). Обзор этого раздела позволяет зафиксировать ту большую напряженную работу, которую проделывала Прасковья Эрдниевна с целью пополнения фондов научной библиотеки, а также выявления новых фактов в изучении проблем калмыковедения. В целом анализ архивного фонда позволяет представить широкий круг творческих интересов ученого, а также очертить значительный вклад П. Э. Алексеевой как неутомимого исследователя в развитие калмыцкой науки.

* Материалы, изложенные в статье, апробированы в виде доклада на заседании Круглого стола «Собиратель сокровищ истории и культуры калмыцкого народа», посвященного 95-летию со дня рождения Почетного гражданина Республики Калмыкия, Заслуженного работника культуры Калмыцкой АССР, главного библиографа Научной библиотеки и архива КалмНЦ РАН П. Э. Алексеевой. 
Благодарность. Исследование проведено в рамках государственной субсидии - проект «Комплексное исследование процессов общественно-политического и культурного развития народов Юга России» (№ госрегистрации: АААА-А19-119011490038-5).

Для цитирования: Топалова Д. Ю. Обзор личного фонда П. Э. Алексеевой. Монголоведение. 2019;(1):90-108. DOI 10.22162/2500-1523-2019-1-90-108.

Abstract. The article describes archival materials from a personal fund of P. E. Alekseeva, the founder of the scientific library of Kalmyk Scientific Center of the RAS, a major bibliographer and researcher. On the basis of the archival materials of the fund numbering 426 items - according to the guidelines for on archival affairs - the fond was divided into three sections. The present analysis of each of them (except for the third one containing photographic materials) makes it possible to trace the creative biography of the developer of the fond in detail. The largest group of documents is 'Scientific Works and Creative Materials' contains drafts of published articles and monographs, and was divided into four main subgroups (history, folklore, ethnography and religion, and Kalmyk expatriate community). The second group is 'Correspondence' which contains working letters, namely, between Praskovia E. Alekseeva and Russian and foreign scientists (A. Bormanzhinov, J. Krueger, E. E. Langerfeld, F. D. Chulman , S. Yu. Neklyudov, etc.). A review of this section provides an opportunity to trace the immense and hard work done by Praskovia E. Alekseeva to increase the fonds of the institution's scientific library, as well as to identify new facts in problems of Kalmyk studies. In general, the analysis of the archive fond allows represents a wide range of creative interests of the scientist, and outlines P. E. Alekseeva's significant contribution - a tireless researcher - to the development of Kalmyk science.

Acknowledgements. Research was performed within a government subsidy - project 'Socio-Political and Cultural Development of South Russia's Peoples: a Comprehensive Research of Respective Processes' (State Reg. No. AAAA-A19-119011490038-5).

For citation: Topalova D. A Review of P. E. Alekseeva's Personal Fond. Mongolian Studies. 2019;(1):90-108. DOI 10.22162/2500-1523-2019-1-90-108.

В 2019 г. П. Э. Алексеевой исполнилось 95 лет. Библиограф, исследователь и просто фанат своего дела - всю свою жизнь Прасковья Эрдниевна посвятила книжному миру, а точнее, профессии, которая никогда не была для нее чем-то обособленным, а всегда была ее «вторым дыханием». Подобная увлеченность работой — характерная черта настоящих ученых, чья жизнь, наполненная изнутри светлым и в то же время необыкновенным энтузиазмом, позволяет им совершать значительные открытия, открывая двери в тайны малоизученных или неизвестных проблем. Не для 
одного поколения ученых удивительная во всех отношениях личность П. Э. Алексеевой, с ее исключительной памятью, широкой эрудицией, развитым умом стала своеобразной «энциклопедией», бесценным кладезем, являющимся одновременно и незаменимым источником по неизвестной и малоизвестной информации, и ярким примером осознанной, преданной любви к своему народу, выбранной профессии и калмыцкой науке. Всегда и со всеми она охотно делится самыми разнообразными и интересными фактами, оказывая действенную, незаменимую помощь исследователям. Работы Прасковьи Эрдниевны, без сомнения, внесли значительный вклад в дело сохранения духовно-культурного наследия калмыцкого народа.

Исследовательская деятельность П. Э. Алексеевой носит разносторонний характер. Об этом свидетельствует огромный поток актуальных на сегодня разнотемных публикаций автора. Семнадцать книг, десятки статей и очерков заключают в себе уникальный материал по краеведению. Большую ценность в этом смысле заключает в себе архивный фонд П. Э. Алексеевой, который находится в Калмыцком научном центре РАН.

Цель работы заключается в описании личного фонда П. Э. Алексеевой. Объектом исследования выступает исследовательская деятельность библиографа.

В личном фонде П. Э. Алексеевой под номером 23 насчитывается 426 единиц хранения. В связи с тем, что архив фондообразователя поступал в несколько этапов, научно-техническое оформление архива до конца еще не налажено, в связи с чем его необработанная часть остается временно недоступной для читателей. Большая часть документов фонда машинописного вида, бумаги пронумерованы, озаглавлены автором и практически все датированы.

Задавшись целью описать архивные материалы фонда П. Э. Алексеевой, весь комплекс архивного материала мы решили условно систематизировать, взяв за основу тематический принцип. Исходя из правил системной научно-технической обработки архивных фондов, условно мы выделили в нем четыре раздела: 
«Научные труды и творческие материалы» «Рабочие моменты», «Переписка», «Фотоматериалы».

Первая и самая крупная группа документов - «Научные труды» дает полное представление о широком круге интересов П. Э. Алексеевой. В состав раздела вошли черновые редакции тех публикаций, которые готовились к изданию. Например, материал по фольклору. Особый интерес для читателя представляет материал о жизни и деятельности талантливого ученого-востоковеда, профессора Сергея Андреевича Козина, об известном востоковеде, собирателе музыкального фольклора монголов, бурят и калмыков Андрее Дмитриевиче Рудневе, о неутомимом фанатике калмыцкого фольклора Иван Ивановиче Попове ${ }^{1}$, научное наследие которого хранится в Ростовском областном государственном архиве, а также в архиве Санкт-Петербургского отделения Института востоковедения РАН и др.

Отдельный пласт в большой группе документов «Научные труды» занимают черновики работ автора по вопросам по истории Калмыкии. В этом отношении большое научное значение заключает в себе материал, связанный с историей формирования и боевого пути 110-й Отдельной кавалерийской дивизии. Заслуга исследователя заключается в составлении поименных списков воинов 110-й ОККД, погибших и захороненных на территории Ростовской области, а также участников боевых действий на Дону в 1942 г. в составе 110-й ОККД. Составление и уточнение списка участников Великой Отечественной войны проводилось не только по Калмыцкому району, но и по всей Ростовской области. К этому же тематическому комплексу архивных дел следует отнести материал о ратных подвигах калмыцких бойцов в годы Великой Отечественной войны, о лагерях, созданных немцами для военнопленных, о женщинах на войне, о судьбах воинов, наших земляков, сражавшихся в партизанских отрядах Югославии.

Подняв вопросы исторического прошлого родного народа, как исследователь Прасковья Эрдниевна не могла не обратиться к на-

${ }^{1}$ Более подробно о коллекции калмыцких сказок, собранных И. И. Поповым в донских степях, а также о сохранности этих фольклорных текстов см.: [Убушиева 2017: 139-151]. 
писанию статей о судьбах известных деятелей Калмыкии, а также о лучших представителях калмыцкой интеллигенции. В разделе фонда хранятся черновики работ об известных калмыцких учителях конца XIX - нач. XX в.: Доржи-Джапе и Ольге Кутузовых, Лиджи Нармаеве, об учителе, враче и переводчике Михаиле Бадмаеве, об авторе калмыцко-русских букварей, пособий, собирателе калмыцкого фольклора Наймине Бадмаеве и др.

Кроме того, на основе ценных исторических данных, а также материалах, полученных путем обмена информацией с российскими и зарубежными учеными, исследователю удалось собрать уникальный материал о жизненном и творческом пути тех знаменитых ученых, кто внес значительный вклад в историко-культурное наследие калмыцкого народа. Эти работы, подготовленные Прасковьей Эрдниевной, составили целую серию статей. Например, о Барботе де Марни, профессоре, известном русском геологе, исследователе калмыцкой степи; об Иосифе Бентковском, ученом, впервые представившем анализ истории калмыков Большедербетовского улуса; о Якове Ивановиче Шмидте, известном ученомвостоковеде, академике, занимавшемся тибетологией и переводами с русского на калмыцкий язык религиозных христианских сочинений; об авторе словаря тибетского языка и «Грамматике» Иоганне Иериге ${ }^{1}$, первом калмыковеде в России, и его вкладе в тибетологию и монголоведение и др.

Среди перечисленных материалов есть также черновые материалы о жизни и деятельности учёных-востоковедов и их работы: И. Г. Гмелина, С. Г. Гмелина, П. С. Палласа, И. И. Лепехина, В. Бергмана, И. Э. Фишера, А. А. Бобровникова, Н. Я. Бичурина, Г. Гомбоева, Б. В. Долбежева.

К группе дел «Научные труды» следует отнести материалы по этнографии и религии - в частности, о калмыцких праздниках и калмыцком календаре, о женщине-матери и ее роли в калмыцкой семье, о калмыцком чае, об ойратской (калмыцкой) люльке,

${ }^{1}$ О деятельности И. Иерига при Российской Академии наук во второй половине XVIII в. и об уникальном материале, собранном Иоганном Иеригом во время пребывания в Астраханской губернии о традиционных способах лечения болезней людей и животных у калмыков, см.: [Дюльденко, Пономарев 2016: 97$102]$. 
о православных калмыках и их крещении; по языкознанию - о корнях двуязычия: из истории изучения калмыцкого языка в дореволюционной России, об А. Г. Владыкине, о Джоу Га и Федоре Петрове, о первых преподавателях китайского и маньчжурского языков в России; о путешествиях в конце XIX - начала XX в. известных калмыцких паломников в Центральную Азию (Бааза-Багши из Дунду-хурула, Пурдаш-Очир Джоногруев, Овше Норзунов, Леджин Арлуев, Дари Ээджи, Дамбо Ульянов).

В первом разделе личного фонда П. Э. Алексеевой, помимо черновых вариантов монографий и сборников исследователя с редактурой, также хранятся дополнительные материалы к ним. Эти документы в полной мере фиксируют всю напряженную подготовительную работу автора, а также наглядно иллюстрируют полную историю создания той или иной книги. Так, дело под номером 98 - «Богшрахинский аймак и богшрахинцы» продолжает серию материалов, которую условно можно обозначить как «Из истории о казачьих станицах». В частности, речь идет о Богшрахинском аймаке, известном как Бултуковская сотня, и о судьбах ее уроженцев: солдатах войны, тружениках тыла и спецпереселенцах, а также об известных исторических личностях (о В. Хомутникове, о ламах М. Борманжинове, Л.-Ш. Тепкине, писателе, публицисте и журналисте С. Балыкове, полковнике Г. Тепкине и других калмыках-эмигрантах).

В описи дела, помимо самой книги, хранятся сведения о последних багшах буддийских хурулов Сальского округа Области Войска Донского на 1915 г., записи устных опросов и воспоминаний информантов, статьи из различных калмыцких печатных изданий, в том числе зарубежных, библиографические дополнения с правками автора, характеристики, учетные карточки, трудовые книжки, удостоверения, свидетельства, аттестаты об образовании, грамоты, личные справки людей, а также иллюстративный материал (фотографии).

Подобных вышеназванных документов, выполняющих конструктивную роль, в личном архиве П. Э. Алексеевой достаточно много. Прежде чем обратиться к написанию той или иной работы, Прасковья Эрдниевна вела серьезную предварительную работу, собирала всевозможную информацию, основательно работала в 
информационных центрах различных ведомств, в библиотеках и центральных архивах не только Республики Калмыкия, но и других городов России. В состав таких материалов входят, например, выписки из книги «Опись дел архива Государственного Совета» 1810-1829 гг., копии личных дел калмыцких ученых (например, Уланова Хюрмче Кирсановича, кандидата географических наук), аттестаты об образовании, многочисленные авторефераты диссертаций, записи рассказов информантов, заметки к биографиям, военные билеты, схемы родословных, большое количество копий личных документов, газетные вырезки, рабочие тетради по библиографии «Истории Калмыкии с древнейших времён...» и др. Сюда же следует отнести автобиографию Ц-Д. Номинханова (ксерокопия с подлинника), а также список его опубликованных трудов, список работ В. А. Хомутникова, выписки из книги В. Н. Земскова «Спецпереселенцы», список литературы по депортации калмыцкого народа, блокнот с записями бесед с соотечественниками во время пребывания в США в июне-июле 1993 г. и расшифровка записей и др. Все эти документы не выделены в отдельную единицу хранения, хотя их следовало бы отнести к одному общему делу под названием «Творческие материалы».

Среди документов раздела «Научные труды» особого внимания заслуживает комплекс материалов, ценность которых заключается в том, что все они посвящены малоисследованной проблематике, по определенным причинам долгое время остававшейся под грифом секретности, - истории зарождения и развития калмыцкой эмиграции. Из архивных материалов фонда П. Э. Алексеевой мы узнаём, что в эмиграции жили калмыцкие национальные писатели, художники, функционировали культурные и политические организации, велась просветительская деятельность, издавались газеты, журналы, книги, в сотрудничестве с казаками проводилась активная общественно-политическая работа.

В состав архивного фонда П. Э. Алексеевой входят также рабочие картотеки по калмыцкому языкознанию, по джангароведению, по истории ойратов и калмыков с древнейших времен до 1917 г., по обзору новых изданий из области калмыковедения, по истории Великой Отечественной войны в Калмыкии 1941-1945 гг., исходя 
из содержания которых библиографом, настоящим профессионалом своего дела были составлены библиографические указатели.

Ко второму разделу фонда П. Э. Алексеевой — «Рабочие моменты» следовало бы отнести делопроизводственный массив документов. Однако в содержании архива его нет, за исключением отчетов о командировке, о новых поступлениях в библиотеку и о рациональном использовании библиотечного фонда. Этот момент, безусловно, является ярким свидетельством того, что Прасковья Эрдниевна была сосредоточена все же исключительно на научно-исследовательской работе, занимаясь больше ученой деятельностью.

В разделе «Фотоматериалы» фонда представлено 166 фотографий. Среди них фотографии калмыков-эмигрантов, рабочих встреч, информантов, калмыцких ученых, участников конференций.

В последнем разделе - «Переписка» хранятся письма исключительно официального характера. Их общий объем составляет 17 единиц. Частую переписку Прасковья Эрдниевна вела с российскими и зарубежными учеными. В связи с этим сюжеты эпистолярного материала одинаковы: все письма содержат в себе поисковую информацию. Так, к примеру, активно занимаясь изучением проблемы калмыцкого зарубежья, Прасковья Эрдниевна направила свои усилия на поиск зарубежных калмыцких печатных изданий 1920-1930-х гг., отдельных исторических материалов, переводов, книг по калмыковедению и т. д.

Понятно, что в начале 1990-х гг. малейшая информация, полученная из-за рубежа, была особенно ценной. В связи с этим остановим свое внимание на переписке П. Э. Алексеевой с гражданином США, почетным гражданином Республики Калмыкия Джабом Наминовичем Бурхиновым (1922-2010). В фонде сохранилось 5 писем от Джаба Бурхинова, два из которых продублированы на русском и английском языках.

В теплых письмах адресанта содержится много «возвращенных ценностей». Так, в письме из 3 единиц хранения, датированном от 31 декабря 1989 г., по просьбе адресата сообщается информация о Данаре Нарановне Баяновой (1889-1983), урожденной Улановой, которая приходилась тещей Д. Н. Бурхинову. Вот какую информацию в одном из писем сообщает о ней Джаб Наминович: «В свое 
время она была одной из первых калмычек с высшим образованием. Училась в Санкт-Петербурге. Окончила университет по естественным наукам. В первые годы эмиграции преподавала в русской гимназии. C переездом в Прагу сотрудничала в Калмыцкой комиссии культурных работников <..> [НА КалмНЦ РАН. Ф. 23. Оп. 3. Ед. хр. 3. Л. 21].

В 1925 г. в Праге Д. Н. Баяновой была переведена часть «Джангара», которая впоследствии была опубликована в журнале «Улан Залат» ${ }^{1}$. Положительный отзыв на проделанную работу был получен от В. Л. Котвича. По мнению, Д. Н. Бурхинова, известные академики-монголоведы С. А. Козин, Б. Я. Владимирцов и др., возможно, знали о «первых попытках перевода „Джангара“ калмычкой в 1920-х гг. в Праге...» [НА КалмНЦ РАН. Ф. 23. Оп. 3. Д. 3. Л. 2].

Сообщается, что Д. Н. Баянова также перевела «Капитанскую дочку», «Дубровского», «Скупого рыцаря» А. С. Пушкина, «Недоросля», «Марсельезу» Д. И. Фонвизина и «Краткую историю калмыцких ханов» профессора А. М. Позднеева.

Следует отметить, что в калмыцких эмигрантских журналах («Хонхо», «Улан Залат») были опубликованы все произведения, за исключением «Дубровского», «Скупого рыцаря» А. С. Пушкина, а также «Краткой истории калмыцких ханов» профессора А. М. Позднеева.

Говоря о местоположении этих работ, Д. Н. Бурхинов заметил, что их возможно найти в Чехии, в библиотеках г. Праги. Отмечается, что в скромных эмигрантских условиях проводились «попытки исследования» тем [НА КалмНЦ РАН. Ф. 23. Оп. 3. Д. 3. Л. 3], издавались печатные издания, публикации, но лишь до 1931-1932 гг., т. е. до тех пор, пока правительство Чехословакии выдавало пособия. Исключением в этом смысле служит книга Э. Хара-Давана «Чингис-хан и его наследие» (Белград, 1927 г.) $)^{2}$, ко-

${ }^{1}$ Информация Джаба Бурхинова не совсем точна. Перевод части «Джангара» впервые был опубликован в хрестоматии «Хонхо» и уже позже напечатан в журнале «Улан Залат».

${ }^{2}$ В начале $1990-х$ гг. книгу Э. Хара-Давана «Чингис-хан и его наследие» Д. Н. Бурхинов прислал в библиотеку Калмыцкого института через народного поэта Калмыкии Е. А. Буджалова (1929-2009). 
торую автор издал за свой счет при сотрудничестве с бывшим генералом, историком Ивановым [НА КалмНЦ РАН. Ф. 23. Оп. 3. Д. 3. Л. 2].

Говоря об эмигрантских журналах, Д. Н. Бурхинов отмечает, что страницы изданий интересны с точки зрения изучения вопросов быта, устройства и культуры эмигрантов за рубежом. В целом же калмыки-эмигранты «жили скромно, работали по существу физическим трудом, в особенности в первые 10-15 лет в Западной Европе, на Балканах и в Чехии. Некоторые семьи очень нуждались, люди не могли получить соответствующее образование. Много калмыков, особенно молодых, страдало легочными заболеваниями» [НА КалмНЦ РАН. Ф. 23. Оп. 3. Д. 3. Л. 21]. Таково в нескольких словах было положение довоенной эмиграции.

Возвращаясь к Д. Н. Баяновой (в девичестве - Улановой), Джаб Наминович писал, что, находясь в тех тяжелых условиях, ей было очень трудно заниматься литературным трудом, кроме того, нужно было работать, чтоб содержать семью и дать образование детям. Муж, Санжи Баянович, страдал сахарным диабетом [НА КалмНЦ РАН. Ф. 23. Оп. 3. Д. 3. Л. 21].

В переписке находит отражение вопрос об образовании калмыков-эмигрантов. Отмечается, что, несмотря на все невзгоды и мытарства, в калмыцкой колонии насчитывалось до сотни учащихся в средних учебных заведениях. Некоторым из них удалось окончить чешский университет, получить образование в Европе и США. Последнее касается второй генерации калмыков-эмигрантов. Так, Хонгор Бадминович Уланов, пятый сын Бадмы Нарановича Уланова, окончил филологический факультет Гарвардского университета и является профессором Университета штата Огайо (город Колумбус, штат Огайо). Будучи профессором, специалистом в области филологии, он тесно сотрудничал с Институтом русского языка им. А. С. Пушкина, знал арабский и персидский языки [НА КалмНЦ РАН. Ф. 23. Оп. 3. Д. 3. Л. 21].

Из истории переписки можно понять, что в планах у Д. Н. Бурхинова было написание монографии «История калмыцкой эмиграции». Эту идею Прасковья Эрдниевна особенно поддерживала. В своем письме от февраля 1990 г. она предлагала ему собрать 
воспоминания-рассказы представителей эмиграции, особенно первой и последующей. При обсуждении этого вопроса упоминается имя чешского ученого Йиржи Шима, проживающего в Чехии и занимающегося исследованием вопросов по истории калмыцкой колонии и печатным изданиям Калмыцкой комиссии культурных работников. Прасковья Эрдниевна предлагала Д. Н. Бурхинову связаться и с ним, также сообщается, что на одной из конференций в Бурятии в конце 1980-х гг. с ним встречалась научный сотрудник Калмыцкого института Л. С. Бурчинова [НА КалмНЦ РАН. Ф. 23. Оп. 3. Д. 3. Л. 16, 17].

Идею о написании истории калмыцкой эмиграции Джабу Бурхинову так и не удалось осуществить. В письме от января 1990 г. Джаб Наминович делился краткой структурой будущей работы. Она представлена, главным образом, в виде хронологии основных моментов жизни калмыцкого зарубежья с кратким описанием содержания каждого периода:

- период 1920-1945 гг.

- период 1945-1950 гг. - нахождение в беженских лагерях в Западной Германии: безвыходное положение калмыков и борьба за право иммиграции за океан ввиду дискриминации по расовым признакам...

- период 1950-1950 гг. - процесс иммиграции в США. Деятельность «Калмыцкого Представительства в Западной Европе» по эмиграционным проблемам. Помощь американской общественности в деле иммиграции калмыков в США по статусу «Перемещенные лица» из Западной Германии...

- период 1952-1957 гг. - устройство калмыков-иммигрантов в США. Проблемы и надежды новой жизни в Америке...

- период 1952-1990 гг. - описание некоторых особенностей в психологии и менталитете американских калмыков-эмигрантов. Здесь автор в точечно обозначает те вопросы, которые он планировал поднять: упоминание о 5-6 калмыцких организациях, враждующих между собой, о плохом материальном положении хурулов и о попытках провести в подобных условиях работу по вопросу объединения калмыков;

- о проблеме идентичности и духовной культуры американских калмыков; 
- период 1953-1962 гг. - о деятельности «Калмыцкого Комитета» под руководством самого Д. Н. Бурхинова в защиту прав калмыцкого народа в период его выселения в Сибирь с 1943 по 1957 гг. [НА КалмНЦ РАН. Ф. 23. Оп. 3. Д. 3. Л. 14, 15].

В последнем пункте речь идет о большой миссии, которую оказал Джаб Бурхинов, будучи генеральным секретарем «Калмыцкого представительства в Западной Европе» по вопросам эмиграции калмыков в США, а также представителем и председателем Калмыцкого комитета по освобождению депортированных в СССР калмыков. В начале 1950-х гг. Джаб Наминович добился приема калмыцкой делегации Госдепартамента США и в ООН, где представил меморандум, в котором предлагалось, чтобы Комиссия по правам человека при ООН добилась от советского правительства реабилитации депортированных народов, в том числе и калмыков, высланных навечно.

Спустя пять лет, в 1955 г., в Малайзии, на конференции представителей Азии и Африки, в г. Бандунг, он вновь выступил с докладом по освобождению калмыцкого и других депортированных народов. Позже данная петиция несколько раз высылалась в Международный Красный крест (г. Женева), во все посольства, а также главам нескольких государств. Упорная борьба Джаба Наминовича за права своего народа со временем все-таки дала долгожданный результат. В 1957 г. советское правительство приняло решение о возвращении калмыцкого народа на родину. Впоследствии Д. Н. Бурхинов выпустил книгу «Борьба за гражданские права калмыцкого народа» ${ }^{1}$.

${ }^{1}$ Из переписки П. Э. Алексеевой и Д. Н. Бурхинова несложно сделать вывод о том, что Джаб Наминович был человеком неравнодушным и добрым. Впервые он посетил родную Калмыкию в 1988 г., когда детей, которые лежали в г. Элисте, в детской республиканской больнице, массово заразили ВИЧ-инфекцией. Узнав о большой беде, случившейся на родине, Джаб Наминович привез дорогостоящий прибор - спектрофотометр для диагностики СПИДа. Спустя время много родителей со всех районов Калмыкии, находясь в безвыходном положении, писали Д. Н. Бурхинову письма с мольбой о помощи их больным, искалеченным детям. Откровенных, душераздирающих писем женщин-матерей было весьма большое количество. Некоторые из них он приводит в письме к Прасковье Эрдниевне [НА КалмНЦ РАН. Ф. 23. Оп. 3. Д. 3. Л. 16, 17]. Джаб Наминович всегда оказывал содействие, устраивал в больницу в г. Филадельфии, помогал, по возможности, материально, обращался с публичной просьбой о помощи к калмыцкой обще- 
Из содержания писем Д. Н. Бурхинова, адресованных П. Э. Алексеевой, следует заключить, что все переводы, сделанные калмыками-эмигрантами, а именно Д. Н. Баяновой, а также другие литературные произведения в настоящее время могут храниться в Чехии, в г. Праге, в «Архиве русской эмиграции».

В письме от 30 июля 1994 г. Джаб Наминович упоминает о том, что есть еще некоторые материалы-рукописи Данары Нарановны [НА КалмНЦ РАН. Ф. 23. Оп. 3. Д. 3. Л. 14, 14], однако, какие конкретно, - не указывается. Сообщается лишь, что эти «манускрипты» [НА КалмНЦ РАН. Ф. 23. Оп. 3. Д. 3. Л. 14] написаны на черновиках.

В письме говорится и о рукописях-мемуарах Б. Н. Уланова, однако адресант был уверен, что публиковать их, вероятнее всего, еще рано [НА КалмНЦ РАН. Ф. 23. О. 3. Д. 3. Л. 14, 14]. Вопрос, где находятся упомянутые Джабом Наминовичем материалы и сохранились ли они, остается в настоящее время открытым. Что касается эмигрантских журналов, то все номера «Улан залат» находятся, по его утверждению, в Институте им. Гувера в г. Стэнфорде, в Калифорнии, откуда есть возможность получить их копии. Говоря о наличии книг по калмыковедению, адресант сообщает, что в американских библиотеках их очень мало.

Из содержания писем можно понять, что в личном фонде Джаба Наминовича было немало документов из архива калмыцкой эмиграции. Однако, в связи с тем, что с 1945 г. он принимал активное участие в общественной жизни, большая часть всех материалов оказалась «разбросана по Европе и Америке» [НА КалмНЦ РАН. Ф. 23. Оп. 3. Д. 3. Л. 12]. Что касается архива самого Джаба Наминовича, то вариантов его хранения было несколько. Так, народный поэт Давид Кугультинов советовал Д. Н. Бурхинову передать копии всех материалов в библиотеку им. Салтыкова-Щедрина в Ленинграде, народный писатель Егор Буджалов считал, что фонд следовало бы передать в Национальный архив Республики Калмыкия. Из писем к Прасковье Эрдниевне выясняется, что сам

ственности за рубежом. Кроме того, Джаб Бурхинов занимался ходатайством стипендий на обучение в США десятков студентов из Монголии, Бурятии, Калмыкии. 
Джаб Наминович планировал сдать оригинал своего архива в Колумбийский университет в г. Нью-Йорке, где также хранятся материалы калмыцких американских организаций, а копии прислать в Элисту, в научный архив Калмыцкого института, а также в Монголию. В письме, датированном от февраля 1990 г., написанном П. Э. Алексеевой, выясняется, что главный библиограф планировала организовать «Личный фонд Д. Н. Бурхинова». Однако в научный архив калмыцкого института материал так и не поступил.

Переписка Прасковьи Эрдниевны с профессором Принстонского университета Арашем Борманжиновым также свидетельствует о напряженной исследовательской работе, которую вели оба ученых: поиски и обмен материалами, книгами, рукописями и статьями о донских калмыцких правлениях, о казачьих станицах, их уроженцах и др. - все это нашло отражение в переписке.

Зачастую в своих письмах Араш Борманжинов представлял ряд вопросов, ответы на которые Прасковья Эрдниевна должна была найти (и находила) в федеральных архивных учреждениях России. Так, в одном из писем (дата не указана) подобные вопросы были связаны с поиском архивных документов из Государственного архива Ростовской области. Так, Араша Борманжинова интересовали материалы из фонда станичных правлений: о тринадцати станицах донских калмыков Сальского округа Области Войска Донского до 1917-1920 гг. (Граббевская, Беляевская, Потаповская, Эркетинская и др.), биографические сведения об Иване Ивановиче Попове, его фотоматериалы, а также названия его рукописей, ранее хранившихся в архивном отделе УМВД Ростовской области. Из Ставропольского краевого государственного архива американского ученого интересовала рукопись Г. Н. Прозрителева «Ставропольские калмыки в бытовом и религиозном отношениях (начало 1920-х гг.), архивные данные о князьях ставропольских калмыков Гахаевых, владельцах Большедербетовского улуса до 1908 г., биографические сведения о Е. Чонове, А. Байсанге, О. Норзунове, С. Яванове, Сетенове, бакши Дорджи и др. [НА КалмНЦ РАН. Ф. 23. Оп. 3. Д. 3. Л. 3, 4].

Благодаря налаженному контакту с зарубежными и российскими учеными Прасковье Эрдниевне удавалось собрать большое 
количество материалов, особенно, как выясняется, путем обмена. Несмотря на большой объем работы, она всегда находила время, чтобы помочь своим друзьям-ученым с поиском того или иного материала по калмыковедению. Те, в свою очередь, с таким же большим и искренним ответным желанием поддержать создателя научно-архивного фонда Калмыцкого института со всех концов света высылали ей самые различные материалы. Еще одним подтверждением тому выступают фрагменты переписки П. Э. Алексеевой с профессором Джоном Крюгером ${ }^{1}$, занимавшимся изучением письменных памятников на «ясном письме».

Так, в письме от января 1994 г. Д. Крюгер выражает благодарность за первую бандероль от Прасковьи Эрдниевны со статьями из различных печатных изданий о г. Сарепте и музее, а также за «великолепное издание сутры Доржин Джодва» [НА КалмНЦ РАН. Ф. 23. Оп. 3. Ед. хр. 7. Л. 1].

В ответ профессор обещает переслать фотокопии словаря Генриха Цвика и четырехтомного труда Бергмана [НА КалмНЦ РАН. Ф. 23. Оп. 3. Ед. хр. 7. Л. 1].

В следующем письме Иван Емельянович сообщает о том, что с приготовлением указанных изданий он закончил и вышлет при первой же оказии, если кто-то из американских калмыков поедет в Элисту. Почтой в библиотеку научного института был также выслан сто тринадцатый том журнала американского восточного общества, китайская книга о монгольском фольклоре, а также оттиски некоторых статей ${ }^{2}$ [НА КалмНЦ РАН. Ф. 23. Оп. 3. Ед. хр. 7. Л. 4].

В письме от 2 августа 1995 г. профессор благодарит за письмо, а также за полученные сведения и номера журналов «Мандала» и «Шамбала», высланных П. Э. Алексеевой через Джиджу Андреева. Ответно адресант обещает выслать фотокопию старого текста о калмыках, напечатанного в брошюре от 1744 г. ${ }^{3}$ [НА КалмНЦ РАН. Ф. 23. Оп. 3. Ед. хр. 7. Л. 5].

\footnotetext{
${ }^{1}$ Настоящее имя - Крюгер Иван Емельянович.

${ }^{2}$ Названия и авторы работ профессором Д. Крюгером не указаны.

${ }^{3}$ Имя автора брошюры, о которой упоминает Д. Крюгер, в письме не сообщается.
} 
В письме от 21 апреля 1997 г. Джон Крюгер упоминает и о высланных в библиотеку института 116 томах журнала американских востоковедов. В письме от 4 февраля 1998 г. он сообщает, что занимается собранием писем, адресованных академику Я. И. Шмидту. На тот момент у него насчитывалось их 80 единиц [НА КалмНЦ РАН. Ф. 23. ОП. 3. Ед. хр. 7. Л. 11]. Все письма он намеревался включить в свою книгу.

В библиотеку Калмыцкого института Иван Емельянович планировал отправить несколько ксилографов рукописей, откопированных им в Германии в 1968 г. В июле 1998 г. от Д. Крюгера поступили ксерокопии прекрасных редчайших работ, которых не хватало в фонде научной библиотеки Калмыцкого института: «Алтн герл», «Доржин Джодва», «Алтн Герл» в транслитерации немецкого монголоведа и китаеведа Хениша. Все работы были написаны на старокалмыцкой письменности - «тодо бичиг».

В одном из писем Д. Крюгер [НА КалмНЦ РАН. Ф. 23. Оп. 2. Д. 36. Л. 1-3] сообщил Прасковье Эрдниевне о существовании сборника песен на калмыцком языке, изданного в Париже, в 1937 г. членами французского общества друзей Востока. Образцы песенного творчества были изданы на «тодо бичиг» с транслитерацией, нотным сопровождением и комментариями. Все песни были собраны торгоутской княжной Нирджидмой. Впоследствии Прасковья Эрдниевна подготовила книгу о Принцессе Нирджидме и ее отце принце Палта Ванге. Издание было дополнено разнообразными образцами песенного творчества торгоутов Китая.

В подборке архивных дел под названием «Переписка с зарубежными учеными» обнаруживаются моменты дальнейшего развития событий, связанных с письмами Я. И. Шмидта. В этом смысле интерес представляет благодарственное письмо от 24 апреля 2006 г., адресованное Евгению Евгеньевичу Лангерфельду, от Прасковьи Эрдниевны, которая на тот момент находилась в предвкушении радостного события-получения. Речь в данном случае идет о той самой копии коллекции калмыцких писем Я. Шмидта, о которых уже упоминалось выше в письме Джона Крюгера.

П. Э. Алексеева, вероятно, по каким-то причинам не получив книгу от профессора, обратилась к Е. Е. Лангерфельду с прось- 
бой отксерокопировать книгу с калмыцкими письмами Я. Шмидта [НА КалмНЦ РАН. Ф. 23. Оп. 3. Ед. хр. 2. Л. 23].

В письме от 16 марта 2006 г. Е. Е. Лангерфельд сообщает, что тайно перекопирует книгу с калмыцкими письмами, переплетёт и передаст в Элисту через пастора Стуглферда [НА КалмНЦ РАН. Ф. 23. Оп. 3. Ед. хр. 2. Л. 22]. Летом 2006 г. книга с драгоценной коллекцией калмыцких писем Я. Шмидта уже была в научной библиотеке Калмыцкого института.

В переписке П. Э. Алексеевой фигурирует имя Фрэнка Джозефа Шульмана, доктора филологических наук, библиографа, основателя, азиатского Архивно-Информационного бюллетеня. В одном из своих писем он выражает признательность Прасковье Эрдниевне «за приложенные усилия во имя развития Западного академического сообщества, которое связано с историей и текущими отношениями калмыков и Калмыкии» [НА КалмНЦ РАН. Ф. 23. Оп. 3. Ед. хр. 6. Л. 3].

Подготовленные Прасковьей Эрдниевной библиографические данные по кандидатским и докторским диссертациям (по Калмыкии) были опубликованы Фрэнком Джозефом в периодическом издании «Doctoral dissertations on Asia», редактором которого был он сам. Эти же материалы П. Э. Алексеевой были также включены в докторскую диссертацию Ф. Д. Шульмана по истории Китая и Внутренней Азии (1976-1990). В знак благодарности через профессора А. Борманжинова для Прасковьи Эрдниевны были переданы три номера журнала «Doctoral dissertations on Asia» (выпуски со 2 по 14 1976/77-1991) и три копии докторской диссертации Джозефа Шульмана.

Особый интерес представляет переписка П. Э. Алексеевой и с другими учеными: Григорием Кара, в которой представлена интересная информация относительно венгерских переводов калмыцкого героического эпоса «Джангар», с профессором С. Ю. Неклюдовым, учителем Ново-Гашунской школы Ростовской области Н. Я. Пашковым, дочерью народного писателя Калмыкии А. Г. Балакаева Деляш Балакаевой, председателем калмыцкого общества США Джиджей Андреевым и др. 
Из переписки П. Э. Алексеевой можно узнать, что, помимо обмена ценными материалами и книгами с российскими и зарубежными учеными, дружеские контакты главного библиографа способствовали и тому, что фонды научной библиотеки и архива были значительно пополнены, а сотрудники Калмыцкого института, как выясняется, имели возможность издавать свои статьи в международных изданиях.

Небольшой обзор личного архивного фонда П. Э. Алексеевой позволяет более детально проанализировать и представить активную поисковую работу П. Э. Алексеевой как ученого, ее трепетное отношение к сбору неизвестных фактов по калмыковедению. Ценность фонда заключается в том, что он дает более полное представление о насыщенной и плодотворной работе библиографа, фиксирует широкий круг интересов П. Э. Алексеевой как исследователя. На своем профессиональном поприще Прасковья Эрдниевна получила всеобщее признание. Ее знают, почитают, уважают, обращаются за помощью, а значит, доверяют. Через архивные материалы фонда прослеживаются отдельные черты характера Прасковьи Эрдниевны - стойкость, поразительная сила духа, целеустремленность, прямолинейность и внутренняя культура, которая присуща не каждому.

В одном из писем сама П. Э. Алексеева замечает: она пережила все периоды - трудные, спокойные, трагичные. Думается, что в каждом документе фонда под номером 23 словно слышится дыхание времени. Все работы Прасковьи Эрдниевны - это, по сути, летопись жизни, которую П. Э. Алексеева без остатка посвятила интересам своего народа.

Категориальное понятие «память» проходит «красной нитью» в ее работах. В ближайшем будущем архивный фонд П. Э. Алексеевой будет полностью структурирован. Согласно основным правилам работы с архивными делами, все единицы хранения будут тематически систематизированы. Отметим, что все документы фонда изданы, неопубликованных материалов обнаружено не было. 


\section{Источники}

НА КалмНЦ РАН - Научный архив Калмыцкого научного центра Российской академии наук (фонд 23).

\section{Sources}

Nauchnyi arkhiv Kalmytskogo nauchnogo tsentra RAN [Scientific Archive of Kalmyk Scientific Center of the RAS]. Fond 23.

\section{Литература}

Дюльденко, Пономарев 2016 - Дюльденко А. А., Пономарев Е. Г. Традиционная калмыцкая медицина второй половины XVIII в. (по материалам Иоганна Иерига) // Вестник Калмыцкого института гуманитарных исследований РАН. 2016. № 5. С. 97-102.

Убушиева 2017- Убушиева Д. В. Кумулятивные образцы в коллекции сказок И. И. Попова // Вестник Калмыцкого института гуманитарных исследований РАН. 2017. № 3. С. 139-151.

\section{References}

Dyuldenko A. A., Ponomarev E. G. Traditional Kalmyk medicine in the mid-to-late 18th c. (a case study of Johann Jahrig's materials). Vestnik Kalmytskogo instituta gumanitarnykh issledovaniy RAN. 2016. No. 5. Pp. 7-102. (In Rus.)

Ubushieva D. V. Cumulative fairy tales from I. I. Popov's collection. Vestnik Kalmytskogo instituta gumanitarnykh issledovaniy RAN. 2017. No. 3. Pp. 139-151. (In Rus.) 